\title{
A Method for Determining Avian Influenza Virus Hemagglutinin and Neuraminidase Subtype Association
}

Open-File Report 2018-1102

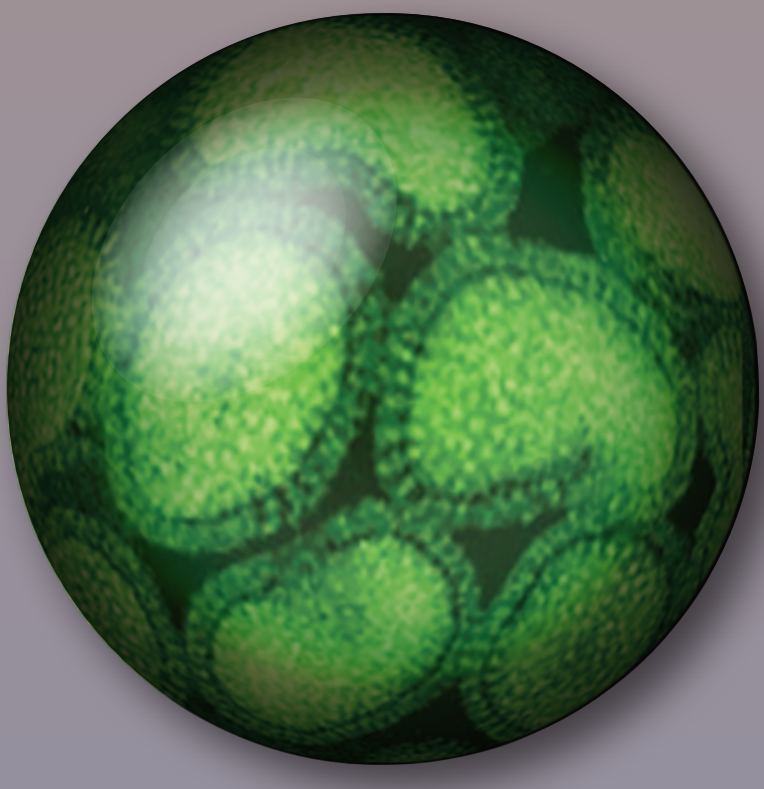

U.S. Department of the Interior

U.S. Geological Survey

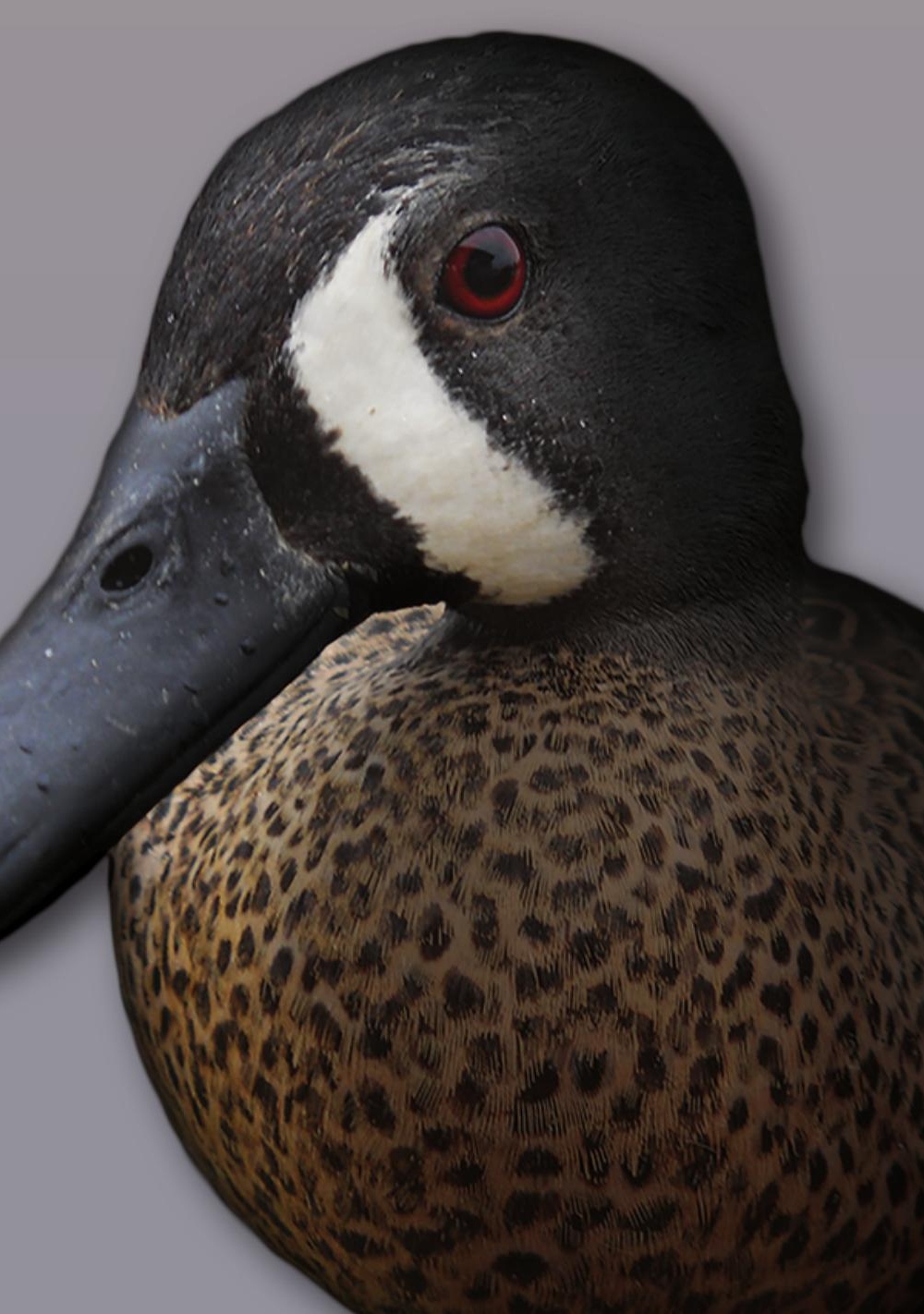


Cover. Photograph of a blue-winged teal by Andy Ramey, U.S. Geological Survey, on March 29, 2013, and image of avian influenza virus modified from photograph by Andy Ramey, U.S. Geological Survey on March 29, 2013. 


\section{A Method for Determining Avian Influenza Virus Hemagglutinin and Neuraminidase Subtype Association}

By Christopher A. Ottinger, Deborah D. Iwanowicz , Luke R. Iwanowicz, Cynthia

R. Adams, Lakyn R. Sanders, and Christine L. Densmore

Open-File Report 2018-1102 


\title{
U.S. Department of the Interior \\ RYAN K. ZINKE, Secretary
}

\author{
U.S. Geological Survey \\ James F. Reilly II, Director
}

U.S. Geological Survey, Reston, Virginia: 2018

For more information on the USGS - the Federal source for science about the Earth, its natural and living resources, natural hazards, and the environment-visit https://www.usgs.gov or call 1-888-ASK-USGS.

For an overview of USGS information products, including maps, imagery, and publications,

visit https://store.usgs.gov.

Any use of trade, firm, or product names is for descriptive purposes only and does not imply endorsement by the U.S. Government.

Although this information product, for the most part, is in the public domain, it also may contain copyrighted materials as noted in the text. Permission to reproduce copyrighted items must be secured from the copyright owner.

Suggested citation:

Ottinger, C.A., Iwanowicz, D.D., Iwanowicz, L.R., Adams, C.R., Sanders, L.R., and Densmore, C.L.,2018, A method for determining avian influenza virus hemagglutinin and neuraminidase subtype association: U.S. Geological Survey Open-File Report 2018-1102, 15 p., https://doi.org/10.3133/ofr20181102.

ISSN 2331-1258 (online) 


\section{Contents}

Abstract
Background
Methods.
Results and Discussion
Acknowledgments
References Cited

\section{Figures}

1. Typical electropherograms of hemagglutinin subtypes evaluated in this study as produced by Agilent's Bioanalyzer DNA 1000 and Agilent's 2100 Expert software...........8

2. Typical electropherograms of neuraminidase subtypes evaluated in this study as produced by Agilent's Bioanalyzer DNA 1000 and Agilent's 2100 Expert software .........10

3. Electropherograms of hemagglutinin and neuraminidase subtypes from a mixed sample containing two avian influenza virus HA:NA subtypes

4. Electropherograms of hemagglutinin and neuraminidase subtypes from a mixed sample containing two avian influenza virus HA:NA subtypes with a shared hemagglutinin subtype

5. Electropherograms of hemagglutinin and neuraminidase subtypes from pond sediment spiked with intact virus of the $\mathrm{H} 4$ : N6 avian influenza virus subtype 


\section{Tables}

1. Isolates of avian influenza viruses from paired cloacal and oropharyngeal swabs inoculated into specific-pathogen-free eggs post screening, purified, and characterized

2. Primers used for subtyping hemagglutinin and neuraminidase genes of purified and characterized isolates of avian influenza virus reverse transcribed into cDNA from purified RNA and amplified using a real-time reverse transcription polymerase chain reaction.

3. Sanger subtype-specific sequence data obtained for avian influenza virus hemagglutinin and neuraminidase subtype target amplicons from this study

4. Representative nucleotide BLAST data for Sanger sequences obtained for avian influenza virus hemagglutinin and neuraminidase subtype target amplicons from this study

5. Quantitative real-time reverse transcription polymerase chain reaction linear regression statistics for hemagglutinin and neuraminidase gene standards used in the assessment of gene copy counts present in the ribonucleic acid from avian influenza virus used in this study

6. Copy count of hemagglutinin and neuraminidase genes obtained from gene copy counts present in the ribonucleic acid from avian influenza virus isolates used in this study, as determined by quantitative real-time reverse transcription polymerase chain reaction

7. Specific amplicon size determined for purified and characterized isolates of avian influenza virus reverse transcribed into complementary deoxyribonucleic acid from purified ribonucleic acid.

8. Corrected HA:NA subtype-specific molar ratios determined for amplicons from purified and characterized isolates of avian influenza virus reverse transcribed into cDNA from purified RNA

9. Results from a mixed sample containing two avian influenza virus HA:NA subtypes....11

10. Results from a mixed sample containing two avian influenza virus HA:NA subtypes sharing a single hemagglutinin subtype 


\section{Conversion Factors}

International System of Units to U.S. customary units

\begin{tabular}{|c|c|c|}
\hline Multiply & By & To obtain \\
\hline \multicolumn{3}{|c|}{ Volume } \\
\hline liter (L) & 33.814 & ounce, fluid (fl. oz) \\
\hline \multicolumn{3}{|c|}{ Mass } \\
\hline gram $(\mathrm{g})$ & 0.035274 & ounce, avoirdupois (oz) \\
\hline
\end{tabular}

Temperature in degrees Celsius $\left({ }^{\circ} \mathrm{C}\right)$ may be converted to degrees Fahrenheit $\left({ }^{\circ} \mathrm{F}\right)$ as follows:

$$
{ }^{\circ} \mathrm{F}=\left(1.8 \times{ }^{\circ} \mathrm{C}\right)+32 \text {. }
$$

Temperature in degrees Fahrenheit $\left({ }^{\circ} \mathrm{F}\right)$ may be converted to degrees Celsius $\left({ }^{\circ} \mathrm{C}\right)$ as follows:

$$
{ }^{\circ} \mathrm{C}=\left({ }^{\circ} \mathrm{F}-32\right) / 1.8 \text {. }
$$

\section{Supplemental Information}

Concentrations of chemical constituents are given in nanogram per microliter ( $\mathrm{ng} \mu \mathrm{L}-1)$ or nanomole per liter ( $\mathrm{nmol} / \mathrm{L})$

\section{Abbreviations}

$\begin{array}{ll}\text { AIV } & \text { avian influenza virus } \\ \text { BLAST } & \text { basic local alignment search tool } \\ \text { BP } & \text { base pairs } \\ \text { cDNA } & \text { complementary deoxyribonucleic acid } \\ \text { CV } & \text { cumulative variance } \\ \text { HA } & \text { hemagglutinin } \\ \text { HPAIV } & \text { high pathology avian influenza virus } \\ \text { NA } & \text { neuraminidase } \\ \text { NCBI } & \text { National Center for Biotechnology Information } \\ \text { NF } & \text { Nuclease free } \\ \text { qPCR } & \text { quantitative polymerase chain reaction } \\ \text { RNA } & \text { ribonucleic acid }\end{array}$

RT-PCR reverse transcription polymerase chain reaction

RT-qPCR reverse transcription quantitative polymerase chain reaction

USGS U.S. Geological Survey 



\title{
A Method for Determining Avian Influenza Virus Hemagglutinin and Neuraminidase Subtype Association
}

\author{
By Christopher A. Ottinger, Deborah D. Iwanowicz , Luke R. Iwanowicz, Cynthia R. Adams, Lakyn R. Sanders, \\ and Christine L. Densmore
}

\section{Abstract}

Methods for grouping specific avian influenza virus (AIV) hemagglutinin (HA) and neuraminidase (NA) subtype reverse-transcription polymerase chain reaction (RT-PCR) products into HA:NA subtypes when egg incubation is technically not feasible were evaluated. These approaches were adopted for use as post hoc methods after melt curve analysis. The methods are based on ratios obtained from amplicon copy count and amplicon molarity and were founded on the premise that infectious particles contain an equal copy count of singlestranded ribonucleic acid segments that encode HA or NA, and thus subtype-specific amplicons from a single AIV isolate should yield a theoretical HA:NA ratio of 1. Single and mixed HA:NA AIV subtype samples were evaluated to determine whether the calculated HA:NA ratios would approach the theoretical value. With these samples, preference was given to the molarity methods to better define and correct for the effects of multiple potential amplicons in the amplification mix. Further, the molarity method was used to evaluate pond sediment spiked with intact virus of known HA:NA subtype to determine whether the method is sufficiently robust to be used with complex samples, such as those acquired from waterfowl habitat. This was a proof-of-concept study intended to guide future methods development. The methods here are not meant to be applied in any other context.

From the analysis of fully characterized isolates of North American AIV, the HA:NA molarity-based ratios were found to be $1.63 \pm 0.75$ (mean \pm standard deviation) when corrected for the difference in amplification strength and the production of multiple amplicons in some reactions using equations developed in this study. Copy count HA:NA ratios, obtained from HA and NA subtype (RT-qPCR), were $1.146 \pm 0.124$ (mean \pm standard deviation) when corrected for amplification efficiency. Correct associations of HA:NA subtype sample composition were made with mixed samples containing $1 \mathrm{HA}$ and 2 NA, and 2 HA and 2 NA. When spiked pond sediment was evaluated, the molar ratio obtained for the $\mathrm{H} 4$ and N6 identified in the sample was 1.28 with correction and 1.14 without correction.

\section{Background}

Avian influenza virus (AIV) poses global threats to food production from domestic animal and human health (Machalaba and others, 2015). Consequently, surveillance programs for AIV in waterfowl populations, and recently (2018) environmental reservoirs, are of increasing importance (Lang and others, 2008). A subset of the known hemagglutinin (HA) subtypes is associated with high pathology AIV (HPAIV). Although changes in HA gene segments are recognized as major components in the transformation of low pathology AIV to HPAIV, changes in neuraminidase (NA) gene segments are also known to contribute to this transformation (Stech and others, 2015). The role of multiple gene segments in the development of HPAIV emphasizes the importance of recognizing not only individual HA and NA subtypes, but also the combined HA:NA subtypes in AIV surveillance programs.

Our interest is in the direct molecular-based characterization of AIV from environmental samples to the level of HA:NA associated subtypes without the need for virus amplification by cell culture. Typical AIV screening utilizes quantitative polymerase chain reaction (qPCR) methodology that includes the use of subtype-specific TaqMan probes for selected virulent subtypes (Payungporn and others, 2006). Holistic screening of AIV diversity in the environment may yield a better understanding of viral ecology. Methods that utilize degenerate primers that amplify the full repertoire of known HA and NA subtypes have been developed (Tsukamoto and others, 2012) but are problematic in terms of HA:NA subtype associations. When single HA and NA subtype genes are characterized from a sample, questions remain as to whether additional subtypes have been lost during the isolation and characterization process. When multiple AIV subtypes are present in a sample, the association of HA and NA into specific HA:NA subtypes can be impossible without additional information. Here we suggest an alternative method for HA:NA subtype association that can assist in this process.

TaqMan- and SYBR Green-chemistry methods have been used in combination with reverse transcription quantitative polymerase chain reaction (RT-qPCR) to evaluate samples for the presence of AIV. The former method is effective for 
diagnostic screening when the exact target AIV subtype is known because the inclusion of a probe increases assay specificity (Payungporn and others, 2006). The latter method has proven useful for surveillance when used with degenerate primer sets that target all known HA and NA subtype genes, where copy count and melt curve analyses are used to determine specificity (Tsukamoto and others, 2012). Tsukamoto and others (2012) produced sample-specific HA and NA subtype lists. This product type, produced from PCR-based AIV genome copy detection, is like that obtained using antibodybased AIV protein detection (Bowman and others, 2015). Product type is the only similarity between these two methods, making direct comparisons of HA and NA subtypes ambiguous. Neither method yields HA:NA subtype associations.

When using TaqMan-chemistry, the grouping of HA and NA subtypes into an HA:NA subtype association occurs by default because only one HA subtype and one NA subtype are targeted using highly specific probes and type-specific methods validation (Payungporn and others, 2006). Alternatively, nothing may be detected, or a single subtype may be detected resulting in a failed or incomplete analysis. A benefit of probe specificity with TaqMan-chemistry is that it increases outcome confidence but it also limits detection when subtype sequence variation or subtype re-assortment occurs. This limitation makes the method less than ideal for environmental surveillance projects intended to detect sequence variation or subtype re-assortment.

When using intercalating dye chemistries such as SYBR Green and primer sets for multiple HA and NA subtypes, which are degenerate to accommodate type-specific sequence variation (Tsukamoto and others, 2012), the confidence associated with high probe specificity is exchanged for breadth of the subtype-specific isolate amplification. Unlike the results obtained using TaqMan-chemistry, when SYBR Greenchemistry is used with multiple subtype primers, no means for subtype association into HA:NA grouping is afforded. Detection of multiple HA and (or) NA subtypes in a single sample can make the determination of HA:NA subtypes problematic without additional information. In theory, the subtype copy count could be used to associate subtypes into HA:NA subtypes because the Influenza A genome consists of single copies of the HA and NA genes (Cheung and Poon, 2007). The copy count ratio of two subtypes that associate to form an HA:NA grouping should approach 1.00. The difficulty with this approach is that validation over a broad range of potential sample mixtures is required. Here, we suggest an alternative solution for the association of HA and NA subtypes into specific HA:NA subtypes and compare the results to results obtained from copy count determinations.

Our alternative approach is a modification of RT-qPCR melt curve analysis (Tsukamoto and others, 2012) using SYBR Green-chemistry and multiple HA and NA primer sets. Applying the same reasoning as used in copy count ratios, we propose the use of molar ratios. Molar ratios are broadly used to describe the composition of complex biomolecules and cellular structures, characterize biochemical interactions, and differentiate normal versus disease states at the subcellular and molecular levels. We are simply applying a classic and well described concept in a different way.

In this proof-of-concept study we evaluated the potential for the practical use of subtype-specific amplicon copy count and molarity in AIV HA:NA subtype association when high throughput sequencing methods are not possible. This approach is applicable to environmental samples containing single or multiple AIV HA:NA groupings. As such, multiple single HA:NA subtypes representing common North American subtypes as well as mixtures of these HA:NA subtypes were evaluated starting with ribonucleic acid (RNA) from fully characterized AIV isolates. As a proof-of-concept, the intent of this study is to inform the development of future methods, and thus the methods here are not meant to be applied in any other context.

This report discusses the methods used in the new alternative approach. Results of this approach are presented in tables and figures.

\section{Methods}

RNA extracted from characterized isolates of multiple subtypes was provided by U.S. Geological Survey (USGS) Alaska Science Center, Anchorage, Alaska (table 1) (Pearce and others, 2009; Pearce and others, 2010; Ramey and others; 2010a; Ramey and others, 2010b; Pearce and others, 2011; Ramey and others, 2011; Reeves and others, 2013). Viral RNA was reverse transcribed using the Applied Biosystems high-capacity complementary deoxyribonucleic acid (cDNA) reverse transcription kit (Life Technologies, Carlsbad, California) with random hexamers from the manufacturer's protocol.

All HA and NA subtypes were analyzed on an Applied Biosystems ViiA 7 real-time qPCR (Life Technologies, Carlsbad, Calif.). PCR with a melt curve analysis was performed as described by Tsukamoto and others (2012) but with modifications. The 20-microliter $(\mu \mathrm{L})$ reaction mixture contained Applied Biosystems Power SYBR Green PCR Master Mix (Life Technologies, Carlsbad, Calif.), 2 micromoles $(\mu \mathrm{M})$ of forward and reverse primers (table 2), and $1 \mu \mathrm{L}$ of cDNA. The cDNA was not normalized prior to amplification nor were starting concentrations measured. The melt curve was used to confirm successful amplification of the correct amplicon using dissociation temperature as described in Tsukamoto and others (2012). Each reaction was run in duplicate except for the control reactions, which were run in triplicate. Replicates were pooled prior to purification.

Post-amplification product purification was performed using the QIAquick PCR Purification Kit and following the manufacture's protocol (Qiagen, Valencia, Calif.). All purified RT-qPCR) products were evaluated using an Agilent Bioanalyzer with Expert Software (Agilent Technologies, Santa Clara, Calif.) with Agilent DNA 1000 Kits and following the manufacturer's protocols. Analysis was performed 
using the default setting, except for height threshold which was reduced to 5 fluorescent units. Potential target amplicons were identified based on maximum observed amplicon molarity determined from subtype-specific reaction products that fell within the assay sensitivity range of 0.1-50 nanograms per microliter (ng $\mu \mathrm{L}-1$ ) (Agilent Technologies) and within the size range of 100-400 base pairs (bp; Tsukamoto and others, 2012). Amplicons from all reactions were sequenced in both directions using Applied Biosystems Big Dye Cycle Sequencing Kit (Foster City, Calif.) to confirm nucleotide sequence. The sequencing reaction profile used consisted of 30 cycles of 20 seconds at 96 degrees Celsius $\left({ }^{\circ} \mathrm{C}\right), 20$ seconds at $58^{\circ} \mathrm{C}$, and 4 minutes at $60{ }^{\circ} \mathrm{C}$, with a 10 -minute extension at $72{ }^{\circ} \mathrm{C}$. The sequencing reactions were cleaned with Agencourt CleanSEQ (Beckman Coulter Genomics, Beckman Coulter Inc., Brea, Calif.), following manufacturer's instructions. Sequencing was carried out on an Applied Biosystems 3130xl Genetic Analyzer (Foster City, Calif.). Biomatters Limited, Geneious R6 software (San Francisco, Calif.) was used to trim and align sequences. Finalized sequences were compared with those published for the specific isolates from which the target amplicons were

Table 1. Isolates of avian influenza viruses from paired cloacal and oropharyngeal swabs inoculated into specific-pathogen-free eggs post screening, purified, and characterized.

[HA, hemagglutinin; NA, neuraminidase; NCBI, National Center for Biotechnology Information; $\mathrm{H}$, identifies hemagglutinin gene; $\mathrm{N}$, identifies neuraminidase gene]

\begin{tabular}{|c|c|c|c|c|c|}
\hline Isolate & HA & NA & $\begin{array}{c}\text { NCBI } \\
\text { accession } \\
\text { number HA }\end{array}$ & $\begin{array}{c}\text { NCBI } \\
\text { accession } \\
\text { number NA }\end{array}$ & Literature cited \\
\hline 3455 & H1 & N9 & HM059985 & HM060041 & $\begin{array}{l}\text { Ramey and } \\
\text { others, } 2010 \mathrm{~b}\end{array}$ \\
\hline 48944 & H1 & N1 & GU168283 & GU168373 & $\begin{array}{l}\text { Ramey and } \\
\text { others,2010a }\end{array}$ \\
\hline 48982 & H1 & $\mathrm{N} 1$ & GU168288 & GU168374 & $\begin{array}{l}\text { Ramey and } \\
\text { others, 2010a }\end{array}$ \\
\hline 49176 & $\mathrm{H} 1$ & N1 & GU168289 & GU168367 & $\begin{array}{l}\text { Ramey and } \\
\quad \text { others, 2010a }\end{array}$ \\
\hline 100756 & $\mathrm{H} 1$ & N1 & GQ411892 & GQ411894 & $\begin{array}{l}\text { Pearce and } \\
\text { others, } 2010\end{array}$ \\
\hline 103775 & H1 & N1 & HM193551 & HM193628 & $\begin{array}{l}\text { Pearce and } \\
\text { others, } 2011\end{array}$ \\
\hline 44927 & $\mathrm{H} 10$ & N7 & GU168309 & GU168402 & $\begin{array}{l}\text { Ramey and } \\
\text { others,2010a }\end{array}$ \\
\hline 44939 & $\mathrm{H} 10$ & N7 & GU168308 & GU168401 & $\begin{array}{l}\text { Ramey and } \\
\text { others, 2010a }\end{array}$ \\
\hline 79190 & $\mathrm{H} 10$ & N9 & HM059988 & HМ060036 & $\begin{array}{l}\text { Ramey and } \\
\text { others, } 2010 \mathrm{~b}\end{array}$ \\
\hline 100870 & $\mathrm{H} 10$ & N1 & JF323753 & JF323778 & $\begin{array}{l}\text { Ramey and } \\
\text { others,2011 }\end{array}$ \\
\hline 134560 & H10 & N7 & JX080780 & JX081172 & $\begin{array}{l}\text { Reeves and } \\
\text { others, } 2013\end{array}$ \\
\hline 40459 & H11 & N9 & JX080738 & JX081129 & $\begin{array}{l}\text { Reeves and } \\
\text { others,2013 }\end{array}$ \\
\hline 101124 & H11 & N9 & JF323755 & JF323789 & $\begin{array}{l}\text { Ramey and } \\
\text { others, } 2011\end{array}$ \\
\hline
\end{tabular}

\begin{tabular}{|c|c|c|c|c|c|}
\hline Isolate & HA & NA & $\begin{array}{c}\text { NCBI } \\
\text { accession } \\
\text { number HA }\end{array}$ & $\begin{array}{c}\text { NCBI } \\
\text { accession } \\
\text { number NA }\end{array}$ & Literature cited \\
\hline 103717 & H11 & N9 & HM193587 & HM193665 & $\begin{array}{l}\text { Pearce and } \\
\quad \text { others, } 2011\end{array}$ \\
\hline 2355 & $\mathrm{H} 2$ & N1 & JX080736 & JX081127 & $\begin{array}{l}\text { Reeves and } \\
\text { others, } 2013\end{array}$ \\
\hline 2366 & $\mathrm{H} 2$ & N1 & JX080744 & JX081135 & $\begin{array}{l}\text { Reeves and } \\
\text { others, } 2013\end{array}$ \\
\hline 2390 & $\mathrm{H} 2$ & N5 & JX080748 & JX081139 & $\begin{array}{l}\text { Reeves and } \\
\text { others, } 2013\end{array}$ \\
\hline 32425 & $\mathrm{H} 2$ & N2 & JX080751 & JX081142 & $\begin{array}{l}\text { Reeves and } \\
\text { others, } 2013\end{array}$ \\
\hline 32921 & $\mathrm{H} 2$ & N3 & JX080765 & JX081157 & $\begin{array}{l}\text { Reeves and } \\
\text { others, } 2013\end{array}$ \\
\hline 13526 & $\mathrm{H} 3$ & N8 & HM193560 & HM193661 & $\begin{array}{l}\text { Pearce and } \\
\text { others, } 2011\end{array}$ \\
\hline 16080 & $\mathrm{H} 3$ & N8 & HM193556 & HM193660 & $\begin{array}{l}\text { Pearce and } \\
\text { others, } 2011\end{array}$ \\
\hline 37536 & $\mathrm{H} 3$ & N8 & JX080757 & JX081148 & $\begin{array}{l}\text { Reeves and } \\
\text { others, } 2013\end{array}$ \\
\hline 44303 & $\mathrm{H} 3$ & N8 & GU143843 & GU168410 & $\begin{array}{l}\text { Ramey and } \\
\text { others, 2010a }\end{array}$ \\
\hline 45315 & $\mathrm{H} 3$ & N6 & GU143852 & GU168393 & $\begin{array}{l}\text { Ramey and } \\
\text { others, 2010a }\end{array}$ \\
\hline 45321 & $\mathrm{H} 3$ & N8 & GU143850 & GU168416 & $\begin{array}{l}\text { Ramey and } \\
\text { others, 2010a }\end{array}$ \\
\hline 104839 & $\mathrm{H} 3$ & N6 & HM193566 & HM193651 & $\begin{array}{l}\text { Pearce and } \\
\text { others, } 2011\end{array}$ \\
\hline 254 & $\mathrm{H} 4$ & N7 & JX080760 & JX081151 & $\begin{array}{l}\text { Reeves and } \\
\text { others, } 2013\end{array}$ \\
\hline 15913 & $\mathrm{H} 4$ & N6 & HM193578 & HM193653 & $\begin{array}{l}\text { Pearce and } \\
\text { others, } 2011\end{array}$ \\
\hline 38800 & $\mathrm{H} 4$ & N6 & JX080742 & JX081133 & $\begin{array}{l}\text { Reeves and } \\
\text { others, } 2013\end{array}$ \\
\hline 49090 & $\mathrm{H} 4$ & N6 & GU168299 & GU168395 & $\begin{array}{l}\text { Ramey and } \\
\text { others, 2010a }\end{array}$ \\
\hline 60390 & $\mathrm{H} 4$ & N6 & HM193576 & HM193652 & $\begin{array}{l}\text { Pearce and } \\
\text { others, } 2011\end{array}$ \\
\hline 103889 & $\mathrm{H} 4$ & N6 & HM193574 & HM193650 & $\begin{array}{l}\text { Pearce and } \\
\text { others, } 2011\end{array}$ \\
\hline 884 & H5 & $\mathrm{N} 2$ & JX080782 & JX081174 & $\begin{array}{l}\text { Reeves and } \\
\text { others, } 2013\end{array}$ \\
\hline 926 & H5 & $\mathrm{N} 2$ & JX080783 & JX081175 & $\begin{array}{l}\text { Reeves and } \\
\text { others, } 2013\end{array}$ \\
\hline 945 & H5 & $\mathrm{N} 2$ & JX080784 & JX081176 & $\begin{array}{l}\text { Reeves and } \\
\text { others, } 2013\end{array}$ \\
\hline 2216 & H5 & $\mathrm{N} 2$ & JX080785 & JX081177 & $\begin{array}{l}\text { Reeves and } \\
\text { others, } 2013\end{array}$ \\
\hline 3850 & H5 & $\mathrm{N} 2$ & JX080756 & JX081147 & $\begin{array}{l}\text { Reeves and } \\
\text { others, } 2013\end{array}$ \\
\hline 13618 & H6 & N2 & FJ520080 & FJ520139 & $\begin{array}{l}\text { Pearce and } \\
\quad \text { others, } 2009\end{array}$ \\
\hline 52796 & H6 & N2 & GU168302 & GU168376 & $\begin{array}{l}\text { Ramey and } \\
\text { others, } 2010 \mathrm{a}\end{array}$ \\
\hline 56526 & H6 & $\mathrm{N} 1$ & FJ520106 & FJ520164 & $\begin{array}{l}\text { Pearce and } \\
\text { others, } 2009\end{array}$ \\
\hline 2320 & $\mathrm{H} 7$ & N7 & JX080762 & JX081154 & $\begin{array}{l}\text { Reeves and } \\
\text { others, } 2013\end{array}$ \\
\hline
\end{tabular}


obtained using the National Center for Biotechnology Information (NCBI) nucleotide Basic Local Alignment Search Tool (BLAST). The size (bp) of confirmed target amplicons was used to generate average amplicon sizes for each HA and NA subtype evaluated in this study.

The copy counts for HA and NA genes in each isolate were quantified using quantitative RT-qPCR. Briefly, RT-qPCR was run using SYBR Green-chemistry with a standard curve for each subtype to calculate the copy count. The RT-qPCR reaction mixture and amplification conditions were the same as those used in melt curve analysis described above. Standards were created using eight dilutions of the purified amplicons from samples of each subtype (table 1) with calculated standard concentrations of $108-101$ copies $/ \mu \mathrm{L}$. The relation between HA and NA copy counts from each isolate was evaluated by calculating HA:NA ratios.

Corrected molar ratios were determined using the following equations:

$$
\frac{\left(\left(H 1 S A M \times\left(\frac{H 1 A S}{N 1 A S}\right)\right) \times\left(\frac{N 1 T M}{H 1 T M}\right)\right)}{N 1 S A M}
$$

$$
\frac{A B S\left(\left(H 1 S A M \times\left(\frac{H 1 A S}{N 1 A S}\right)\right) \times\left(\frac{N 1 T M}{H 1 T M}\right)\right)-\left(N 2 S A M \times\left(\frac{H 1 A S}{N 2 A S}\right) \times\left(\frac{N 2 T M}{H 1 T M}\right)\right)}{N 1 S A M}
$$

and

$$
\frac{\left(\left(H 1 S A M \times\left(\frac{H 1 A S}{N 1 A S}\right)\right) \times\left(\frac{N 1 T M}{H 1 T M}\right)\right)}{A B S\left(N 1 S A M-\left(H 2 S A M \times\left(\frac{H 2 A S}{N 1 A S}\right) \times\left(\frac{N 1 T M}{H 2 T M}\right)\right)\right)}
$$

\begin{tabular}{|c|c|c|}
\hline$A B S$ & is & absolute value, in nanomoles; \\
\hline$H 1 S A M$ or $N 1 S A M$ & is & $\begin{array}{l}\text { specific amplicon molarity of hemagglutinin or neuraminidase subtype under } \\
\text { consideration; }\end{array}$ \\
\hline$H 1 A S$ or $N 1 A S$ & is & $\begin{array}{l}\text { amplification strength as measured by total fluorescence at the end of the terminal } \\
\text { qPCR cycle of hemagglutinin or neuraminidase subtype under } \\
\text { consideration; }\end{array}$ \\
\hline$H 1 T M$ or $N 1 T M$ & is & $\begin{array}{l}\text { total molarity observed for all amplicons, including the subtype-specific amplicon } \\
\text { from subtype-specific product analysis of hemagglutinin or neuraminidase } \\
\text { subtype under consideration; }\end{array}$ \\
\hline$H 2 S A M$ or $N 2 S A M$ & is & $\begin{array}{l}\text { similar to H1SAM or N1SAM, except that values are those used to correct for the } \\
\text { molarity contribution of subtype not considered in ratio; }\end{array}$ \\
\hline$H 2 A S$ or $N 2 A S$ & is & $\begin{array}{l}\text { similar to H1AS or N1AS, except that values are those used to correct for the } \\
\text { molarity contribution of subtype not considered in ratio; and }\end{array}$ \\
\hline$H 2 T M$ or $N 2 T M$ & is & $\begin{array}{l}\text { similar to H1TM or N1TM, except that values are those used to correct for the } \\
\text { molarity contribution of subtype not considered in ratio. }\end{array}$ \\
\hline
\end{tabular}

where 
Table 2. Primers used for subtyping hemagglutinin and neuraminidase genes of purified and characterized isolates of avian influenza virus reverse transcribed into cDNA from purified RNA and amplified using a real-time reverse transcription polymerase chain reaction. ${ }^{1}$

[cDNA, complementary deoxyribonucleic acid; RNA, ribonucleic acid; bp, base pairs; $\mathrm{H}$, identifies hemagglutinin gene; $\mathrm{N}$, identifies neuraminidase gene; C, cytosine; G, guanine; A, adenine; T, thymine; B, mixed base C/G/T; D, mixed base A/G/T; H, mixed base A/T/C; K, mixed base G/T; M, mixed base A/C; $\mathrm{R}$, mixed base $\mathrm{A} / \mathrm{G} ; \mathrm{V}$, mixed base $\mathrm{A} / \mathrm{C} / \mathrm{G} ; \mathrm{W}$, mixed base $\mathrm{A} / \mathrm{T} ; \mathrm{Y}$, mixed base $\mathrm{C} / \mathrm{T}]$

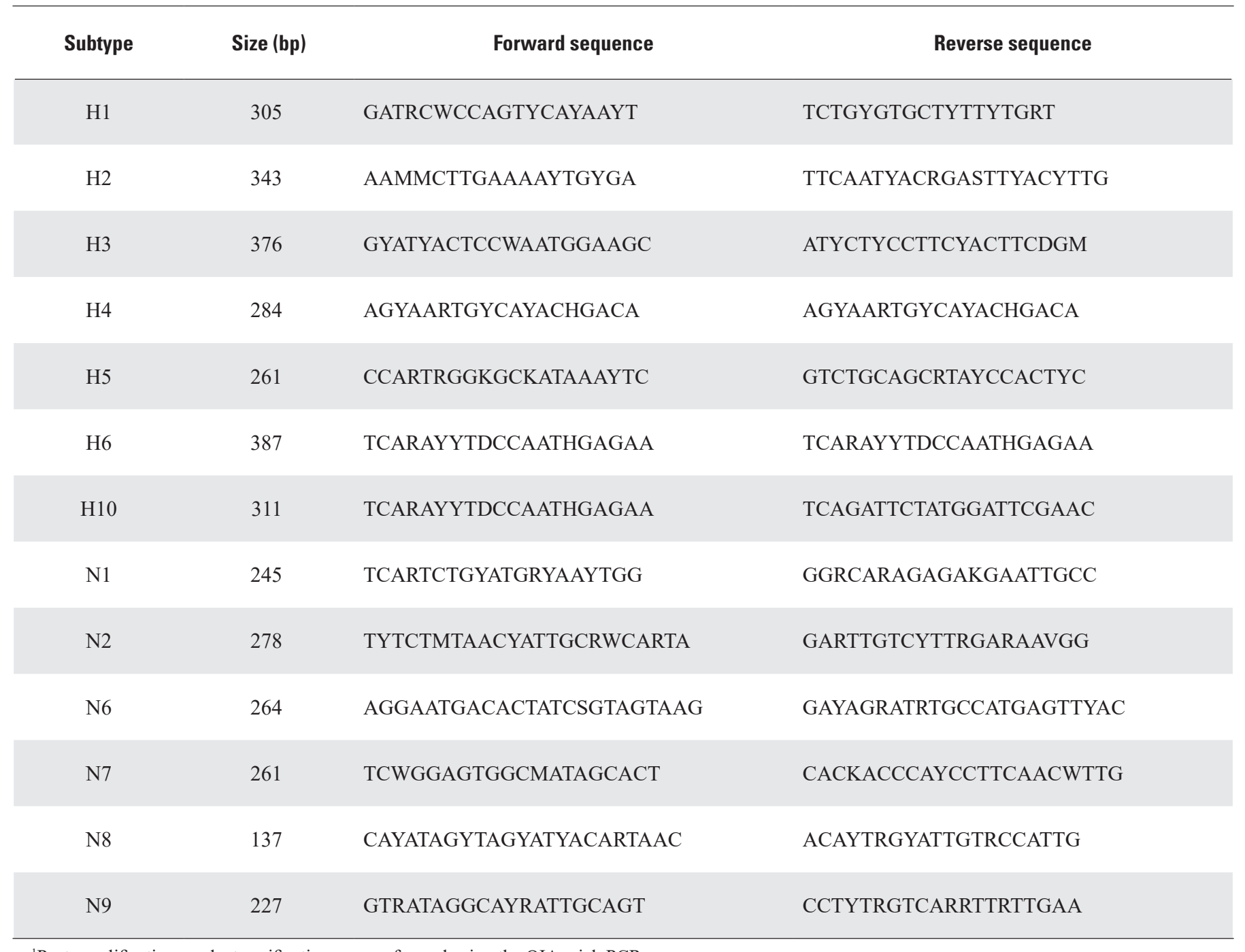

${ }^{1}$ Post-amplification product purification was performed using the QIAquick PCR.

The equations for corrected molar ratios were derived as modifications of the simple HA:NA ratio. Amplification strength was used to correct for the production of non-target amplicons, a phenomenon associated with SYBR Greenchemistry (Wittwer and others, 1997) that may have a negative effect on final target amplicon concentrations. The use of total molarity had a similar function correct for the occurrence of non-target amplicons in a size range of 100-1,000 bp. Equations used to calculate corrected molarity when two HA:NA subtypes with a shared HA or NA subtype occurred (eqs. 2 and 3 ) were developed to account for the molarity of one subtype being divided between two other subtypes. The equation for situations where $1 \mathrm{NA}$ and 2 HA subtypes are detected (eq. 3) is provided, but an example is not presented to avoid redundancy.
Target amplicon molarity was taken from the standard Agilent 2100 Expert software output. Total sample molarity was calculated by obtaining the sum of molarities from each double-stranded DNA sample component that was $100-1,000 \mathrm{bp}$ in size and within the quantitative range of the assay. Amplification strength was determined from qPCR output for each reaction by measuring total fluorescence at the end of cycle 30. Standardized values of amplification strength were determined by dividing 1,000,000 by the reaction-specific fluorescence. In this calculation, amplification strength decreases as the standardized values increase. To facilitate ease of comparison, corrected molar ratios calculated to be between 0.01 and 0.99 were converted to a value greater than 1 by dividing 1 by the calculated value.

Chicken-egg allantoic fluid containing viable H4:N6 virus was used to produce a "spiked" pond sediment. Total 
RNA was then extracted using a RNA PowerSoil Total RNA Isolation Kit (Mo Bio) and following the manufacture's protocol. Initial virus concentrations were in an expected range of 105-107 virus per milliliter (mL-1) of allantoic fluid (Hon S. Ip, USGS, written commun., 2016). Sediment was obtained from a pond used by overwintering waterfowl and was a mix of silt, sand, and vegetation. Two spiked sediment samples and one negative control sediment sample were evaluated. Each sample and the negative control contained $2.00 \pm 0.05$ grams ( $\mathrm{g}$ ) of sediment. Total spike volume was
$1 \mathrm{~mL}$. The final concentration of the first spike sample was in the range of 105-107 virus per g- 1 of sediment. The second spiked sample contained a 1:10 dilution of the first spike with the dilution performed in RNAase- and DNAase-free molecular grade water (NF water). The negative control sample was treated with $1 \mathrm{~mL}$ of NF water only. Both alcohol precipitation steps used in the RNA extraction process were performed for 30 minutes at $-20^{\circ} \mathrm{C}$. Conversion of extracted RNA to cDNA, RT-qPCR amplification, and analysis of PCR products using the Bioanalyzer were performed as described above.

Table 3. Sanger subtype-specific sequence data obtained for avian influenza virus hemagglutinin and neuraminidase subtype target amplicons from this study. ${ }^{1}$

[H, identifies hemagglutinin gene; $\mathrm{N}$, identifies neuraminidase gene; $\mathrm{C}$, cytosine; $\mathrm{G}$, guanine; $\mathrm{A}$, adenine; $\mathrm{T}$, thymine]

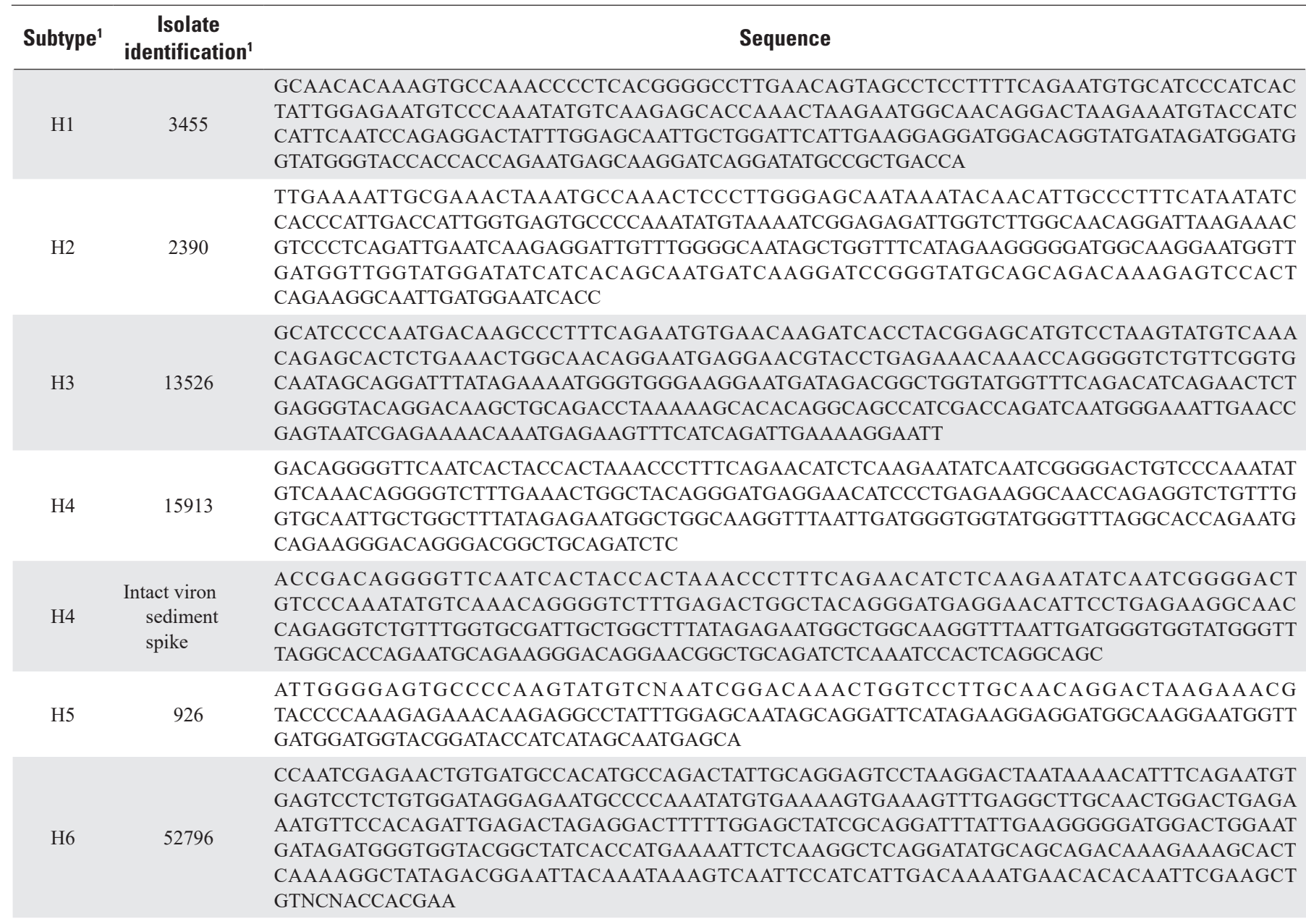

AATCTTTCCCCGAGAACTGTGGGTCAATGCCCCAAGTATGTGAACAAAAAGAGCCTGTTGCTTGCTACTG GAATGAGGAATGTGCCAGAGGTTGTCCAAGGAAGAGGCCTGTTTGGAGCAATAGCTGGATTCATAGAGAATG H10 134560 GATGGGAAGGAATGGTAGATGGTTGGTATGGTTTCCGACACCAAAATGCCCAAGGCACTGGCCAGGCCGCG GATTATAAAAGTACTCAGGCAGCTATAGATCAAATAACCGGGAAATTGAACAGACTGATAGAGAAGACAAACA CAGAGTTCGAATCCATAGAATCTGAA

N1 48982 CAGAACTATCCCGAAACATGCAATCAAAGTGTCATTACCTACGAAAACAATACTTGGGTGAATCAGACATACAT CAACATAAGTAATACCAATTTAATTTCAGAACAGGCTGTAGCTCCAGTAACACTAGCAGGCAATTCCTCTCTCT

CANTATGTTTCCTCATGCAAATTGCCATCCTAGCAACGACTATAACACTGCACTTCAAGCAGAATGAATGCAT CATCCCCTCGAACAATCAAGTAGTGCCATGTGAGCCAATCATAGTAGAAAGGAACATAACAGAGATAGTGTATT N2 $\quad 52796$ TAAATAATACCACCATAGAAAGAGAACTTTGTCCTAANTTAACAGANATACAGGGATTGGTCGAAACCACAGTGT CAGATC 
Table 3. Sanger subtype-specific sequence data obtained for avian influenza virus hemagglutinin and neuraminidase subtype target amplicons from this study. ${ }^{1}$ - Continued

[H, identifies hemagglutinin gene; $\mathrm{N}$, identifies neuraminidase gene; $\mathrm{C}$, cytosine; $\mathrm{G}$, guanine; $\mathrm{A}$, adenine; $\mathrm{T}$, thymine]

\begin{tabular}{|c|c|c|}
\hline Subtype $^{1}$ & $\begin{array}{c}\text { Isolate } \\
\text { identification'1 }\end{array}$ & Sequence \\
\hline N6 & 60390 & $\begin{array}{l}\text { GGGGCTGAACATTGGGCTTCATTTCAAGGTAGGAGACACACCAGAACCAGGACCCCCTAGTACCAATGAGA } \\
\text { CAAACTCCACAACCGCAATAATCAATTACAACACCCAAAACAACTTCACAAATGTGACCAACATTGTGTTGATTA } \\
\text { AAGAAGAAAACAAAATGTTCACNANCCTTTCTAAGCCCTTGTGTGAAGTN }\end{array}$ \\
\hline N6 & $\begin{array}{l}\text { Intact viron } \\
\text { sediment } \\
\text { spike }\end{array}$ & $\begin{array}{l}\text { GCTGAACATTGGGCTTCATTTCAAGGTAGGAGACACACCAGAAACAGGAACCCCTAGTACCAATGAGA } \\
\text { CAAACTCCACAACCACAATAATCAACTACAACACCCAAAACAACTTCACAAATGTGACCAACATTGTGTTAATTA } \\
\text { AAAAAGAAAACAAAATGTTCACAAACCTTTCTAAGCCCTTGTGTGAAGTGAACTCATGGCACATCCT }\end{array}$ \\
\hline N8 & 13526 & $\begin{array}{l}\text { ATAGTTAGCATTACAGTAACAGTGTTAGTTCTCCCTGGAAATGGAAATAATGGGGGTTGCAATGAANCAGT } \\
\text { CATTAGGGAATACAATGAAACAGTAAGAGG-TTGAGAAGG-TAACACAATTTACCAATGTC }\end{array}$ \\
\hline
\end{tabular}

${ }^{1}$ Isolates used in this study. For additional information see table 1.

Table 4. Representative nucleotide BLAST data for Sanger sequences obtained for avian influenza virus hemagglutinin and neuraminidase subtype target amplicons from this study.

[BLAST, Basic Local Alignment Search Tool; H, identifies hemagglutinin gene; N, identifies neuraminidase gene; NCBI, National Center for Biotechnology Information]

\begin{tabular}{|c|c|c|c|c|c|c|c|c|}
\hline \multirow{2}{*}{ Subtype $^{1}$} & \multirow{2}{*}{$\begin{array}{c}\text { Isolate } \\
\text { identification' }\end{array}$} & \multirow{2}{*}{$\begin{array}{c}\text { NCBI accession } \\
\text { number for } \\
\text { published data }{ }^{1}\end{array}$} & \multicolumn{6}{|c|}{ BLAST metrics } \\
\hline & & & $\begin{array}{l}\text { Sequence } \\
\text { range }\end{array}$ & Score & $\begin{array}{l}\text { Query } \\
\text { cover }\end{array}$ & $\begin{array}{c}\text { Expected } \\
\text { (E value) }\end{array}$ & Identities & Gaps \\
\hline $\mathrm{H} 1$ & 3455 & HM059985 & $885-1,152(268)$ & 496 & $98 \%$ & $2 \mathrm{E}-144$ & $100 \%$ & $0 \%$ \\
\hline $\mathrm{H} 2$ & 2390 & JX080748 & $871-1,182(312)$ & 577 & $99 \%$ & $9 \mathrm{E}-169$ & $100 \%$ & $0 \%$ \\
\hline $\mathrm{H} 4$ & 15913 & HM193578 & $888-1,139(252)$ & 466 & $100 \%$ & $2 \mathrm{E}-135$ & $100 \%$ & $0 \%$ \\
\hline H4 & $\begin{array}{c}\text { Intact virus } \\
\text { sediment spike }\end{array}$ & CY076205.1 & $896-1,167$ (272) & 492 & $99 \%$ & $2 \mathrm{E}-135$ & $99 \%$ & $0 \%$ \\
\hline H5 & 926 & JX080783 & $914-1,086(173)$ & 316 & $100 \%$ & $1 \mathrm{E}-90$ & $99 \%$ & $0 \%$ \\
\hline N1 & 48982 & GU168374 & $18-259(230)$ & 425 & $99 \%$ & $6 \mathrm{E}-123$ & $98 \%$ & $0 \%$ \\
\hline N2 & 52796 & GU168376 & $29-252$ (219) & 405 & $98 \%$ & $2 \mathrm{E}-117$ & $99 \%$ & $0 \%$ \\
\hline N6 & 60390 & HM193652 & $84-278(191)$ & 353 & $99 \%$ & $8 \mathrm{E}-102$ & $99 \%$ & $0 \%$ \\
\hline N6 & $\begin{array}{c}\text { Intact virus } \\
\text { sediment spike }\end{array}$ & CY076191.1 & $96-302(207)$ & 377 & $98 \%$ & $5 \mathrm{E}-11$ & $99 \%$ & $0 \%$ \\
\hline N7 & 134560 & JX081172 & $20-252(233)$ & 431 & $100 \%$ & $4 \mathrm{E}-125$ & $100 \%$ & $0 \%$ \\
\hline N8 & 13526 & HM193661 & $72-206(135)$ & 241 & $100 \%$ & $4 \mathrm{E}-68$ & $99 \%$ & $0 \%$ \\
\hline N9 & 10124 & JF323789 & $75-268$ (194) & 359 & $100 \%$ & $2 \mathrm{E}-103$ & $100 \%$ & $0 \%$ \\
\hline
\end{tabular}

${ }^{1}$ Isolates used in this study. For additional information see table 1. 


\section{Results and Discussion}

Development of these assays was intended to be applied as a post hoc analysis of the Tsukamoto and others (2012) melt curve method. The use of RT-qPCR and molar ratios as described here is strictly intended as a component in the characterization of environmental samples that are evaluated using molecular methods only. Fragment size analysis provides confirmation of amplicon size and an opportunity to determine molar ratios in the presence of multiple HA:NA subtypes in a single sample. AIV genomic RNA from egg culture was used to validate the suggested method.

Subtype-specific sequence data (table 3 ) for potential target amplicons were consistent with the published data for the isolates from which the amplicons were produced (table 4).
Isolate specific copy count HA:NA ratios obtained from HA and NA subtype RT-qPCR were $1.146 \pm 0.124$ (mean \pm standard deviation). Ratio values ranged from 1.028 to 1.509 . Statistical metrics for the RT-qPCR, including amplification efficiency (table 5) and isolate specific subtype copy counts (table 6), are provided. Electropherograms for HA (fig. 1) and NA (fig. 2), including amplicon size and molarity values, are typical of Bioanalyzer DNA 1000 chip output when evaluated using Agilent 2100 Expert software to compare amplicons with the included standard ladder. Based on the ladder as the sample, the Agilent DNA 1000 performance metrics are as follows (Agilent Technologies): sizing accuracy of \pm 10 percent, a sizing reproducibility of 5-percent cumulative variance $(\mathrm{CV})$, quantitation accuracy of 20 percent $\mathrm{CV}$, and quantitation reproducibility
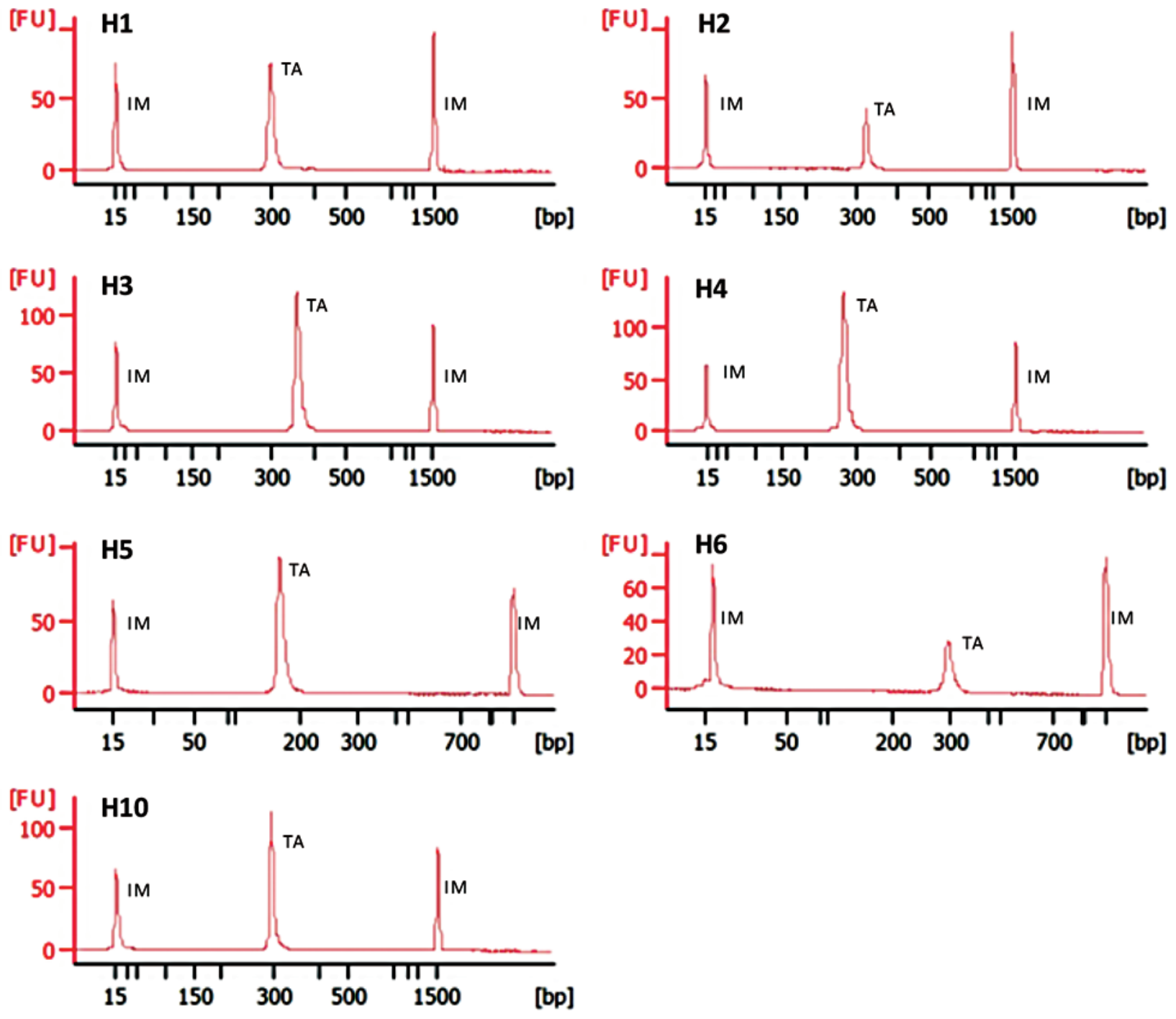

Figure 1. Typical electropherograms hemagglutinin subtypes evaluated in this study as produced by Agilent's Bioanalyzer DNA 1000 and Agilent's 2100 Expert software. Analyses produced from purified and characterized isolates reverse transcribed into deoxyribonucleic acid from purified ribonucleic acid, amplified by reverse transcription quantitative polymerase chain reaction, and then evaluated for amplicon size and molarity. Subtype identification is associated with each graph. 
Table 5. Quantitative real-time reverse transcription polymerase chain reaction linear regression statistics for hemagglutinin and neuraminidase gene standards used in the assessment of gene copy counts present in the ribonucleic acid from avian influenza virus used in this study.

$\left[\mathrm{r}^{2}\right.$, coefficient of determination; $\mathrm{H}$, identifies hemagglutinin gene; $\mathrm{N}$, identifies neuraminidase gene $]$

\begin{tabular}{|c|c|c|c|c|c|}
\hline Subtype & Slope & y-intercept & $\mathbf{r}^{2}$ & Percent amplification efficiency & Error \\
\hline H1 & -3.818 & 41.829 & 1 & 82.778 & 0.016 \\
\hline $\mathrm{H} 2$ & -3.442 & 35.125 & 0.996 & 95.968 & 0.043 \\
\hline $\mathrm{H} 3$ & -3.831 & 38.908 & 0.996 & 82.402 & 0.055 \\
\hline H5 & -3.648 & 39.442 & 0.992 & 87.998 & 0.068 \\
\hline H6 & -3.711 & 37.791 & 0.997 & 85.972 & 0.045 \\
\hline $\mathrm{H} 10$ & -3.427 & 37.992 & 0.998 & 95.798 & 0.034 \\
\hline $\mathrm{N} 2$ & -4.326 & 45.098 & 0.992 & 70.27 & 0.09 \\
\hline N6 & -3.334 & 36.952 & 0.992 & 99.499 & 0.062 \\
\hline N7 & -0.354 & 36.199 & 0.997 & 92.91 & 0.045 \\
\hline N8 & -3.872 & 41.275 & 0.999 & 81.255 & 0.019 \\
\hline N9 & -3.822 & 39.307 & 0.998 & 82.645 & 0.036 \\
\hline
\end{tabular}

Table 6. Copy count of hemagglutinin and neuraminidase genes obtained from gene copy counts present in the ribonucleic acid from avian influenza virus isolates used in this study, as determined by quantitative real-time reverse transcription polymerase chain reaction.

[H, identifies hemagglutinin gene; $\mathrm{N}$, identifies neuraminidase gene]

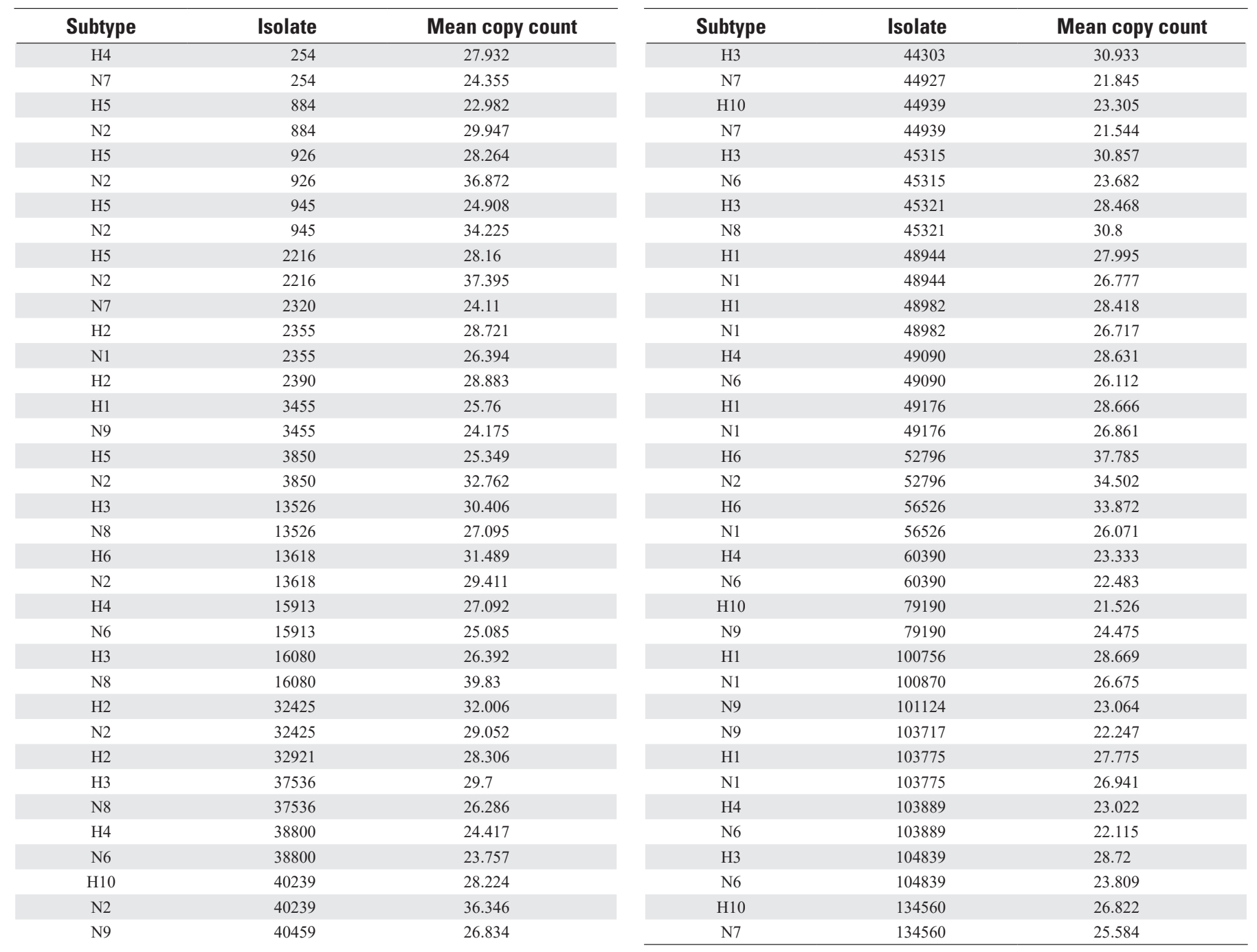


of 15 percent $\mathrm{CV}$ within the $25-500$ bp range. Reactions involving a single HA:NA subtype produced a single amplicon in most of the amplifications. In reactions that did exhibit multiple amplicons, the products were less than $100 \mathrm{bp}$ in size and thus outside the expected range for the desired amplification products.

Results of analysis of amplicon size indicate that the primary product of reactions involving a single HA:NA grouping and targeting a single HA or NA subtype could vary considerably from published values (table 7; Tsukamoto and others, 2012). Target amplicons that varied from published values by more than $10 \mathrm{bp}$ were all smaller than the published values and were mostly HA subtypes, except for N6. Departures from published values tended to increase with increasing amplicon size (data not shown). Calculated standard deviations of amplicon sizes were all low, ranging from 1 to 3 .

Corrected molar ratios (eq. 1) obtained for 36 isolates from 13 HA:NA subtypes had a mean \pm standard deviation $(\mathrm{SD})$ of $1.63 \pm 0.75$. Corrected molar ratio calculations produced values (table 8 ) closer to theoretical perfect value of 1 relative to the simple HA:NA ratio for 22 of the 32 isolates with an improvement toward 1 of $4.50 \pm 7.70($ mean \pm SD) relative to the simple HA:NA ratio. In the 10 cases where the simple ratio produced values closer to the ideal value of 1 , improvement relative to the corrected molar ratio was $0.30 \pm 0.36$. In HA:NA subtypes for which there were at least four isolates analyzed, corrected molar ratio mean \pm standard deviation values were as follows: $\mathrm{H} 1: \mathrm{N} 11.74 \pm 0.13$, $\mathrm{H} 3: \mathrm{N} 81.41 \pm 0.42, \mathrm{H} 4: \mathrm{N} 61.12 \pm 0.07, \mathrm{H} 5: \mathrm{N} 22.67 \pm 1.15$.

In mixed samples containing two HA:NA types (fig. 3), the lowest corrected molar ratios (eq. 2) created subtype associations of H3:N8 and H4:N6 (table 9), which accurately reflect the types included in the equation. The H4:N6 combination exhibited the lowest corrected molar ratio (1.09). The $\mathrm{H} 3$ : N8 combination had a lower ratio (2.03) than the alternative H3:N6 (2.13), indicating that, from an $\mathrm{H} 3$ perspective, H3:N8 would be a more viable combination. Pairings are based on the closest fit to the ideal value of 1.00 . The combinations of $\mathrm{H} 3$ :N8 and H4:N6 provide the closest fits for the two HA:NA pairing. Single-size appropriate amplicons were recognized in each of these reactions. The corrected molar ratio for H4:N6 was very close to the mean value for H4:N6 isolates evaluated as a single HA:NA subtype. The actual isolate used in this mix, isolate 49090, (table 8) exhibited a corrected molar ratio 0.05 less when run as a single HA:NA subtype compared to the value obtained when the
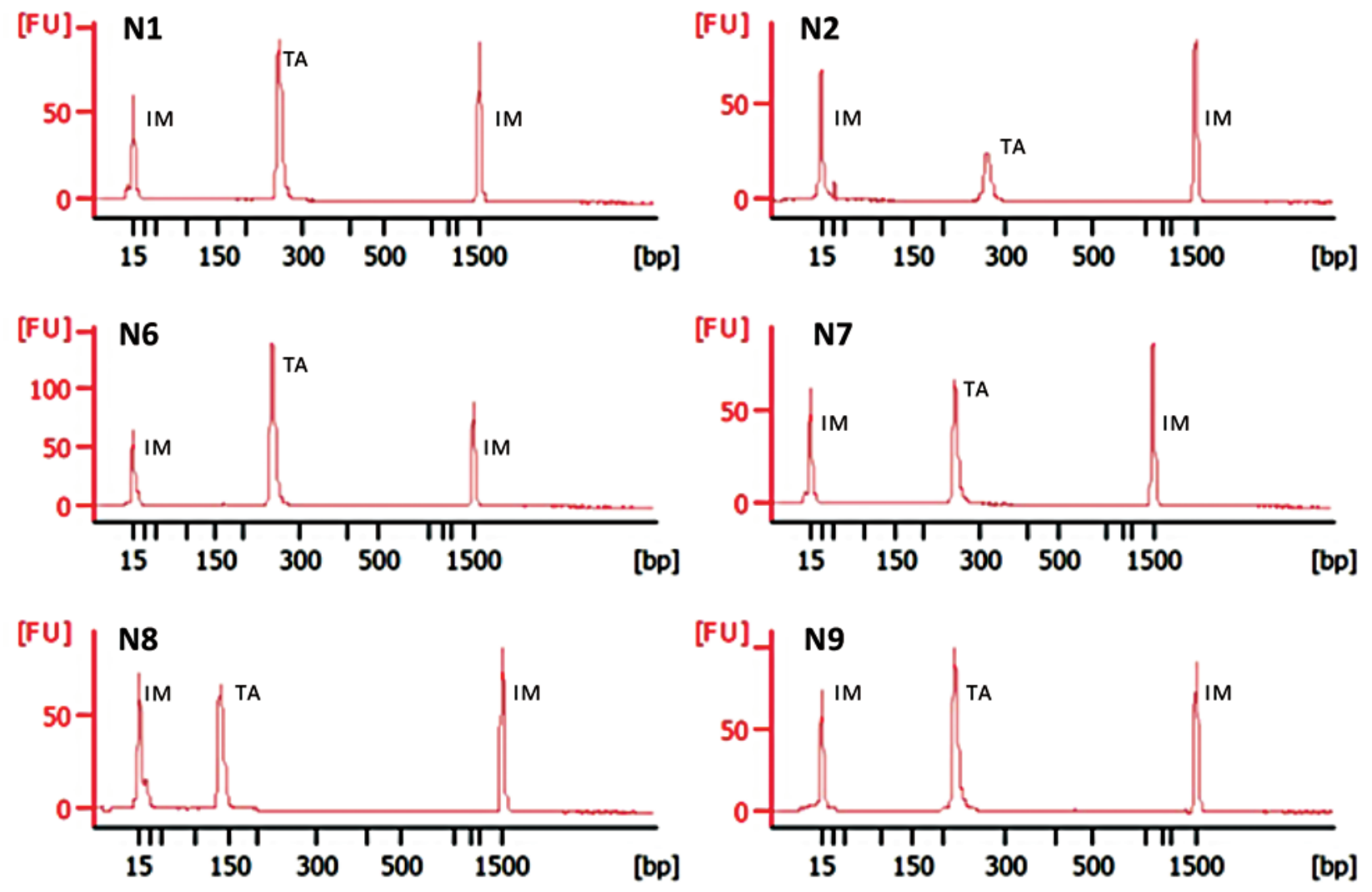

Figure 2. Typical electropherograms of neuraminidase subtypes evaluated in this study as produced by Agilent's Bioanalyzer DNA 1000 and Agilent's 2100 Expert software. Analyses produced from purified and characterized isolates reverse transcribed into deoxyribonucleic acid from purified ribonucleic acid, amplified by reverse transcription quantitative polymerase chain reaction, and then evaluated for amplicon size and molarity. Subtype identification is associated with each graph. 
Table 7. Specific amplicon size determined for purified and characterized isolates of avian influenza virus reverse transcribed into complementary deoxyribonucleic acid from purified ribonucleic acid.

[SD, standard deviation; bp, base pair]

\begin{tabular}{|c|c|c|c|c|c|c|c|}
\hline Subtype & $\begin{array}{l}\text { Number of } \\
\text { isolates }\end{array}$ & $\begin{array}{c}\text { Mean } \pm \\
\text { SD amplicon } \\
\text { size (bp) }\end{array}$ & $\begin{array}{c}\text { Departure from } \\
\text { published value } \\
\text { (bp) }\end{array}$ & Subtype & $\begin{array}{c}\text { Number of } \\
\text { isolates }\end{array}$ & $\begin{array}{c}\text { Mean } \pm \\
\text { SD amplicon } \\
\text { size }(b p)^{1}\end{array}$ & $\begin{array}{c}\text { Departure from } \\
\text { published value } \\
\text { (bp) })^{1,2}\end{array}$ \\
\hline \multicolumn{4}{|c|}{ Hemagglutinin } & \multicolumn{4}{|c|}{ Neuraminidase } \\
\hline $\mathrm{H} 2$ & 5 & $327 \pm 2$ & -16 & N2 & 8 & $269 \pm 2$ & -9 \\
\hline $\mathrm{H} 4$ & 6 & $275 \pm 1$ & -10 & N7 & 5 & $260 \pm 3$ & -1 \\
\hline H6 & 2 & ${ }^{3} 361,365$ & -24 & N9 & 4 & $219 \pm 1$ & -8 \\
\hline
\end{tabular}

${ }^{1}$ Value rounded to nearest whole number. Actual amplicon sizes provided for $\mathrm{H} 6$.

${ }^{2}$ From Tsukamoto and others, 2012; based on amplicon mean size.

${ }^{3}$ Mean and standard deviation not determined; 363 used in applicable comparisons.

Table 8. Corrected HA:NA subtype-specific molar ratios determined for amplicons from purified and characterized isolates of avian influenza virus reverse transcribed into cDNA from purified RNA.

[cDNA, complementary deoxyribonucleic acid; RNA, ribonucleic acid; HA or $\mathrm{H}$, hemagglutinin; NA or N, neuraminidase]

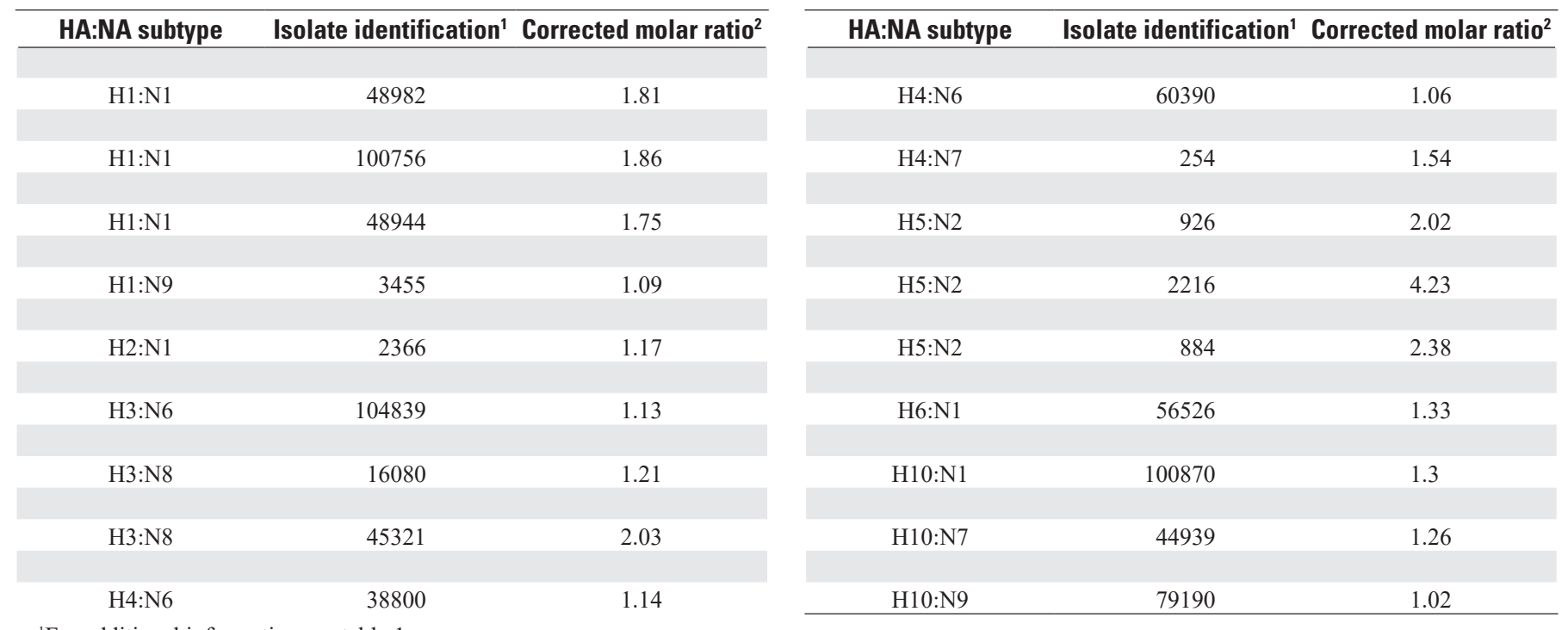

${ }^{1}$ For additional information see table 1.

${ }^{2}$ To facilitate ease of comparison, corrected molar ratios calculated to be between 0.01 and 0.99 were converted to a value greater than one as follows: $1 /$ calculated value.

Table 9. Results from a mixed sample containing two avian influenza virus HA:NA subtypes. Mix produced from purified ribonucleic acid extracted from characterized isolates of avian influenza virus which was reverse transcribed into deoxyribonucleic acid, amplified by quantitative polymerase chain reaction, and then evaluated for amplicon size and molarity.

[bp, base pair; nmol/L, nanomoles per liter; FU, fluorescent unit; HA:NA, hemagglutinin:neuraminidase; H, identifies hemagglutinin gene; N, identifies neuraminidase gene]

\begin{tabular}{|c|c|c|c|c|c|c|c|}
\hline Subtype & $\begin{array}{l}\text { Predicted } \\
\text { fragment } \\
\text { size (bp) }\end{array}$ & $\begin{array}{c}\text { Observed } \\
\text { fragment } \\
\text { size (bp) }\end{array}$ & $\begin{array}{c}\text { Observed } \\
\text { molarity } \\
\text { (nmol/L) }\end{array}$ & $\begin{array}{l}\text { Amplification } \\
\text { strength [FU] }\end{array}$ & $\begin{array}{c}\text { Total } \\
\text { molarity } \\
\text { (nmol/L) }\end{array}$ & $\begin{array}{c}\text { Potential } \\
\text { HA:NA } \\
\text { subtype }\end{array}$ & $\begin{array}{c}\text { Corrected } \\
\text { molar } \\
\text { ratio }^{1}\end{array}$ \\
\hline $\mathrm{H} 3$ & 358 & 357 & 7.5 & 4.83 & 7.5 & H3:N6 & 2.13 \\
\hline N6 & 252 & 258 & 26.5 & 2.09 & 26.5 & H4:N6 & 1.09 \\
\hline N8 & 137 & 135 & 21.4 & 12.70 & 27.6 & H4:N8 & 1.23 \\
\hline
\end{tabular}

${ }^{1}$ Calculated as per equation 2 . 
isolate was part of this mixture. The $\mathrm{H} 3$ :N8 ratio was outside one single standard deviation for isolates of this HA:NA subtype but was identical to the value obtained from the isolate 45321, which was used in the mixture (table 8).

A second mixed sample containing two HA:NA subtypes was evaluated (fig. 4). In this mix, only three subtypes were present $(\mathrm{H} 4, \mathrm{~N} 6, \mathrm{~N} 7)$, requiring the use of a different equation for calculating corrected molar ratios (eq. 3). Here, where
H4 was the only HA subtype, the corrected molar ratios with N6 and N7 (table 10) were within one standard deviation of the mean from the 31 isolates evaluated individually. The H4 and N7 subtype-specific amplifications produced multiple amplicons with a larger contribution of these additional products to total molarity observed for H4. The H4:N6 corrected ratio was outside one standard deviation of ratios obtained for H4:N6 isolates evaluated in isolation. The corrected ratio for
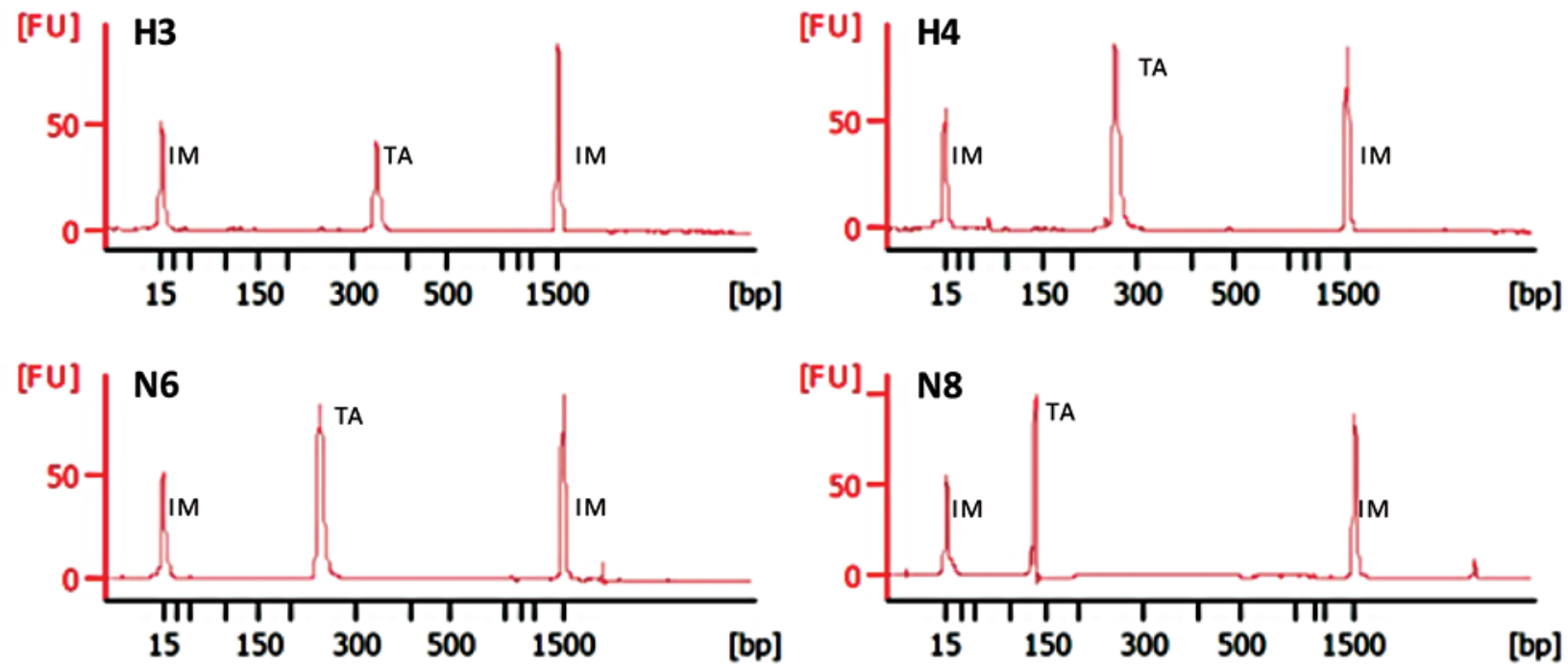

Figure 3. Electropherograms of hemagglutinin and neuraminidase subtypes from a mixed sample containing two avian influenza virus HA:NA subtypes. Analytes produced from purified and characterized isolates reverse transcribed into deoxyribonucleic acid from purified ribonucleic acid, amplified by quantitative polymerase chain reaction, and then evaluated for amplicon size and molarity. Subtype identification is associated with each graph.

(HA:NA, hemagglutinin: neuraminidase; bp, base pair; FU, fluorescent unit; H, identifies hemagglutinin gene; N, identifies neuraminidase gene; IM, internal marker; TA, subtype-specific target amplicon)
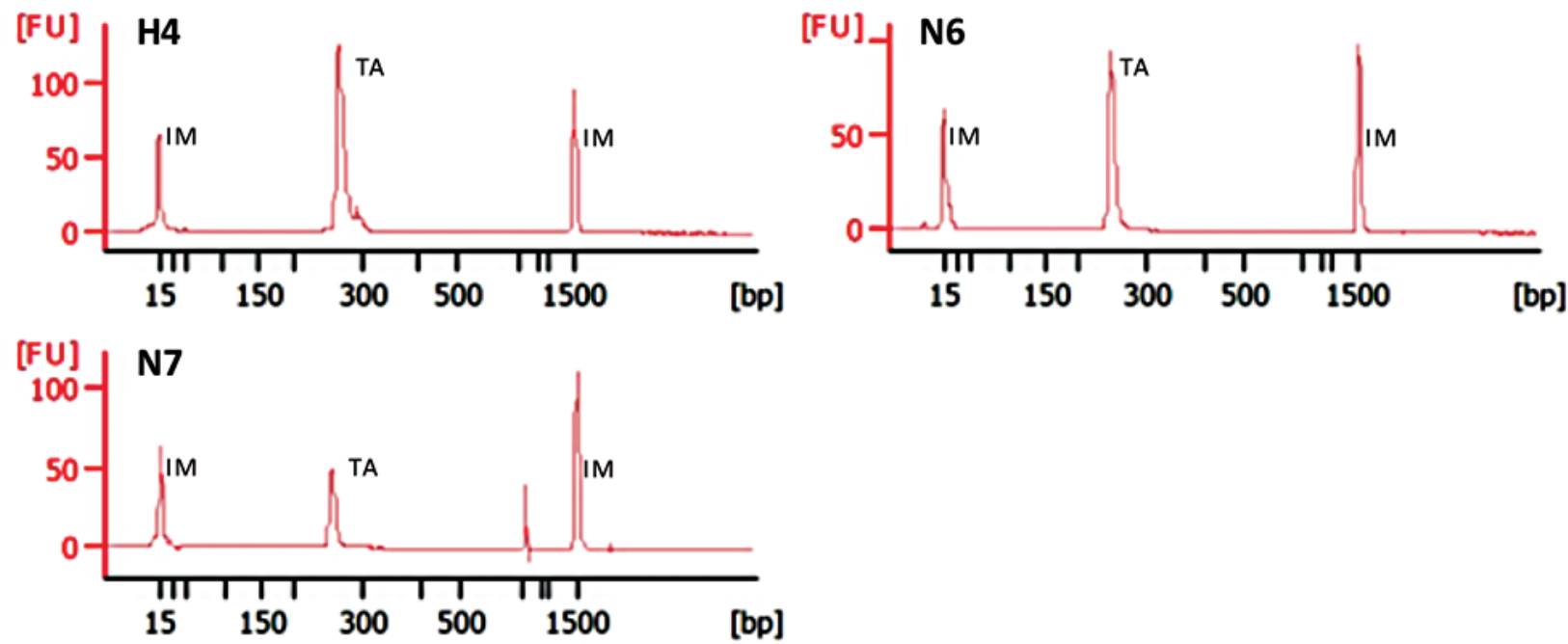

Figure 4. Electropherograms of hemagglutinin and neuraminidase subtypes from a mixed sample containing two avian influenza virus HA:NA subtypes with a shared hemagglutinin subtype. Analytes produced from purified and characterized isolates reverse transcribed into deoxyribonucleic acic from purified ribonucleic acid, amplified by quantitative polymerase chain reaction, and then evaluated for amplicon size and molarity. Subtype identification is associated with each graph. 
H4:N7 was slightly lower than the ratio obtained when this HA:NA subtype was evaluated alone (table 8).

To evaluate the efficacy of the method as it relates to environmental samples, we spiked sediment acquired from a pond used by migratory waterfowl using intact virions of the H4:N6 subtype. Our intent here was to simulate actual methods that would be used in environmental surveillance. Analysis of amplified products for H4 and N6 revealed single products in the 100-1,000 bp range (fig. 5). Amplification strengths for H4 and N6 were 1.71 and 2.19, respectively, which are consistent with amplification strength for these subtypes when evaluated directly from allantoic fluid (tables 9 and 10). Molar ratios determined for the spiked H4:N6 were 1.28 (corrected) and 1.14 (not corrected). These values are like those obtained for H4:N6 from allantoic fluid (table 8), indicating that the inclusion of an environmentally relevant substrate had little effect on analysis outcome. The identities of the H4 and N6 subtypes were confirmed by sequencing (tables 3 and 4).

As indicated in process results, the use of RT-qPCR was more effective at establishing ratios closer to the ideal value of 1 , as shown by the lower ratio mean \pm standard deviation values obtained from the copy count, relative to those produced using corrected molar ratios. Further, the use of amplification efficiency provides a simpler means of ratio correction for AIV RNA obtained from egg cultures.

The relatively high concentrations of RNA from other organisms obtained from direct extraction of environmental samples and the potential variation in the concentration and sequence of this RNA complicates the determination of amplification efficiency by essentially forcing an efficiency determination for each HA and NA subtype in each sample. The use of molar ratios was an attempt to circumvent this issue. Correction of molar ratios from the simple HA:NA equation was necessary because of relative differences in the observed degree of amplification (matrix effect) and because of the production of multiple non-specific products in some reactions. The requirement for determining some measure of amplification efficiency was not eliminated using molarity measures.

Our objective was to evaluate the use of molarity in AIV HA:NA subtype grouping, using robust conditions while still using purified and fully characterized isolates to facilitate methods development. Our final goal was to provide a method application for processes in which RNA extractions are performed directly from samples without intervening viral proliferation steps. The difference in sequence-confirmed target amplicon size relative to those reported by Tsukamoto and others (2012) contributed to the potential variation

Table 10. Results from a mixed sample containing two avian influenza virus HA:NA subtypes sharing a single hemagglutinin subtype. Mix produced from purified ribonucleic acid extracted from characterized isolates of avian influenza virus which was reverse transcribed into deoxyribonucleic acid, amplified by quantitative polymerase chain reaction, and then evaluated for amplicon size and molarity.

[bp, base pair; nmol/L, nanomoles per liter; FU, fluorescent unit; HA:NA, hemagglutinin:neuraminidase; H, identifies hemagglutinin gene; N, identifies neuraminidase gene; --, no additional information intended]

\begin{tabular}{|c|c|c|c|c|c|c|c|}
\hline Subtype & $\begin{array}{l}\text { Predicted } \\
\text { fragment } \\
\text { size (bp) }\end{array}$ & $\begin{array}{c}\text { Observed } \\
\text { fragment } \\
\text { size (bp) }\end{array}$ & $\begin{array}{l}\text { Observed } \\
\text { molarity } \\
\text { (nmol/L) }\end{array}$ & $\begin{array}{l}\text { Amplification } \\
\text { strength [FU] }\end{array}$ & $\begin{array}{c}\text { Total } \\
\text { molarity } \\
\text { (nmol/L) }\end{array}$ & $\begin{array}{c}\text { Potential } \\
\text { HA:NA } \\
\text { subtype }\end{array}$ & $\begin{array}{c}\text { Corrected } \\
\text { molar } \\
\text { ratio }^{1}\end{array}$ \\
\hline $\mathrm{H} 4$ & 275 & 267 & 47.8 & 2.15 & 51.5 & H4:N6 & 2.04 \\
\hline N6 & 252 & 248 & 32.9 & 2.32 & 32.9 & H4:N7 & 1.21 \\
\hline N7 & 260 & 254 & 14.5 & 4.04 & 15.0 & -- & -- \\
\hline
\end{tabular}

${ }^{1}$ Calculated using equation 3 .
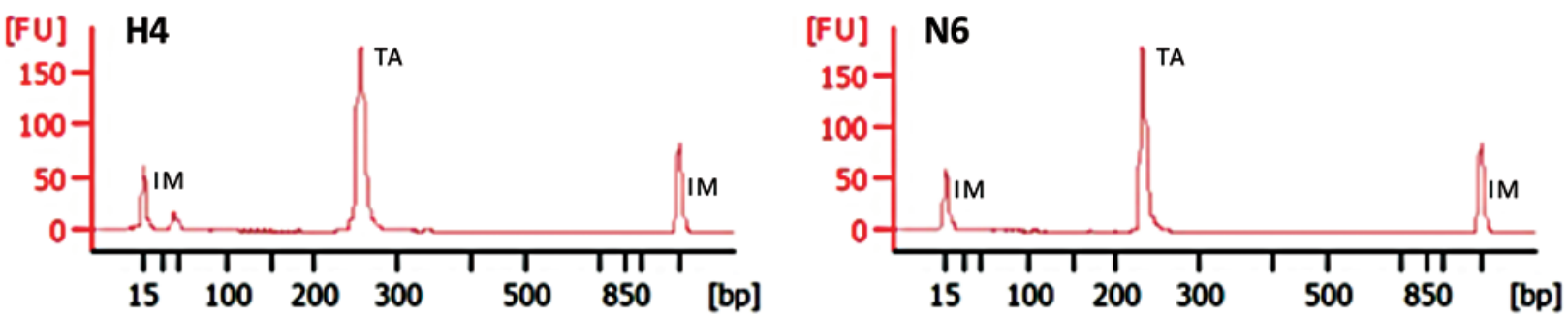

Figure 5. Electropherograms of hemagglutinin and neuraminidase subtypes from pond sediment spiked with intact virus of the H4:N6 avian influenza virus subtype. Analytes produced from reverse transcribed deoxyribonucleic acid from purified virus ribonucleic acid, amplified by quantitative polymerase chain reaction, and then evaluated for amplicon size and molarity. Subtype identification is associated with each graph.

(bp, base pair; FU, fluorescent unit; H, identifies hemagglutinin gene; N, identifies neuraminidase gene; TA, subtype-specific target amplicon; IM, internal marker; bp, base pair) 
that was encountered. The isolates used by Tsukamoto and others (2012) were not evaluated, and a different type of qPCR instrument and different reagents were used. The reason for the observed difference in amplicon size was not determined. We can, however, point out that even when all other things are equal, there can be variation in amplicon size within a subtype (table 7) that supersedes known instrument accuracy and reproducibility tolerances. Amplicon size is directly related to molarity and thus to corrected molarity ratios.

Simple HA:NA copy ratios produced from RT-qPCR and molarity can accurately associate AIV HA and NA subtypes into HA:NA groupings. Isolates from some HA:NA subtypes can yield ratios that approach the theoretically perfect value of 1.00, whereas isolates from other HA:NA subtypes consistently produce higher ratios, indicating the presence of HA:NA subtype isolate dependency. Further, the same or very similar ratios can be obtained from isolates whether they are analyzed individually or in an amalgam. The method is not perfect in that we could not account for the increase in corrected molar ratios involving the H4:N6 subtype in mixed samples. Some primer sets used in this study clearly produce amplicons besides those intended, as seen in the electropherograms and in total product molarity. The current equations (eqs. 1-3) take such products into account but do not completely compensate for their effects on the ratio outcome. Despite the imperfections, the method is sufficiently robust to be applicable to complex samples, such as pond sediment. When selecting the RT-qPCR and molarity approaches to group HA and NA subtypes into HA:NA subtypes, we recognized that the same objectives can be accomplished with next generation sequencing technologies, particularly using amplicon resequencing. Such an approach has a distinct advantage in that sequence data are generated directly, thus avoiding the need for follow-up Sanger sequencing to confirm amplicon identity. The results obtained in this study, while promising, are limited in scope and do not completely address the full spectrum of potential issues involved with the association of HA:NA subtypes. Future methods development for the identification of HA:NA subtypes would likely benefit from the inclusion of next-generation sequencing technologies to accelerate the development process and further characterize process requirements.

\section{Acknowledgments}

We extend our sincere appreciation to Dr. Andy Ramey of the USGS Alaska Science Center for providing us with the avian influenza virus (AIV)-isolate ribonucleic acid (RNA) used in this study and to Dr. Hon Ip of the USGS National Wildlife Health Center for the isolated virus he provided to Dr. Ramey, making our receipt of the RNA possible. We also thank Dr. Ip for the intact AIV used in our sediment spike experiment.

\section{References Cited}

Bowman, A.S., Nolting, J.M., Massengill, R., Baker, J., Workman, J.D., and Slemons, R.D., 2015, Influenza A virus surveillance in waterfowl in Missouri, USA, 2005-2013: Avian Diseases, v. 59, p. 303-308. [Also available at https://doi.org/10.1637/11002-121014-Reg.]

Cheung, T.K.W., and. Poon, L.L.M., 2007, Biology of influenza A virus, in Lal, S.K., ed., Biology of emerging viruses: SARS, Avian and human influenza, metapneumovirus, Nipah, West Nile, and Ross River Virus: Annals of the New York Academy Science, v. 1102, p. 1-25.

Lang, A.S., Kelly, A., and Runstadler, J.A., 2008, Prevalence and diversity of avian influenza viruses in environmental reservoirs: Journal of General Virology, v. 89, p. 509-519. [Also available at https://doi.org/10.1099/vir.0.83369-0.]

Machalaba, C.C., Elwood, S.E., Forcella, S., Smith, K.M., Hamilton, K., Jebara, K.B., Swayne, D.E., Webby, R.J., Mumford, E., Mazet, J.A.K., Gaidet, N., Daszak, P., and Karesh, W.B., 2015, Global avian influenza surveillance in wild birds: A strategy to capture viral Diversity: Emerging Infectious Diseases, v. 21, p. e1-e7, accessed January 25, 2018, at https://wwwnc.cdc.gov/eid/article/21/4/14-1415_ article.

Payungporn, S., Chutinimitkul, S., Chaisingh, A., Damrongwantanapokin, S., Buranathai, C., Amonsin, A., Theamboonlers, A., and Poovorawan, Y., 2006, Single step mutilplex real-time RT-PCR for H5N1 influenza A virus detection: Journal of Virological Methods, v. 131, p. 143-147. [Also available at https://doi.org/10.1016/j. jviromet.2005.08.004.]

Pearce, J.M., Ramey, A.M., Flint, P.L., Koehler, A.V., Fleskes, J.P., Franson, J.C., Hall J.S., Derksen, D.V., and Ip, H.S., 2009, Avian influenza at both ends of a migratory flyway: Characterizing viral genomic diversity to optimize surveillance plans for North America: Evolutionary Applications, v. 2, p. 457-468. [Also available at https://doi.org/10.1111/ j.1752-4571.2009.00071.x.]

Pearce, J.M., Ramey, A.M., Ip, H.S., and Gill R.E., 2010, Limited evidence of trans-hemispheric movement of avian influenza viruses among contemporary North American shorebird isolates: Virus Research, v. 148, p. 44-50. [Also available https://doi.org/10.1016/j.virusres.2009.12.002.]

Pearce, J.M., Reeves, A.B., Ramey, A.M., Hupp, J.W., Ip, H.S., Bertram, M., Petrula, M.J., Scotton, B.D., Trust, B., Meixell, K.A., and Runstadler, J.A., 2011 Interspecific exchange of avian influenza virus genes in Alaska: The influence of trans-hemispheric migratory tendency and breeding ground sympatry: Molecular Ecology, v. 20, p. 1015-1025. [Also available at https://doi.org/10.1111/ j.1365-294X.2010.04908.x.] 
Ramey, A.M., Pearce, J.M., Ely, C.R., Sheffield Guy, L.M., Irons, D.B., Derksen, D.V., and Ip, H.S., 2010a, Transmission and reassortment of avian influenza viruses at the Asian-North American interface: Virology, v. 406, p. 352-359. [Also available at https://doi.org/10.1016/j. virol.2010.07.031.]

Ramey, A.M., Pearce, J.M., Flint, P.L., Ip, H.S., Derksen, D.V., Franson, J.C., Petrula, M.J., Scotton, B.D., Sowl, K.M., Wege, M.L., and Trust, K.A., 2010b, Intercontinental reassortment and genomic variation of low pathogenic avian influenza viruses isolated from Northern Pintails (Anas acuta) in Alaska: Examining the evidence through space and time: Virology, v. 401, p.179-189.

Ramey, A.M., Pearce, J.M., Reeves, A.B., Franson, J.C., Petersen, M.R., and Ip, H.S., 2011, Evidence for limited exchange of avian influenza viruses between seaducks and dabbling ducks at Alaska Peninsula coastal lagoons: Archives of Virology, v. 156, p. 1813-1821. [Also available at https://doi.org/10.1007/s00705-011-1059-z.]

Reeves, A.B., Pearce, J.M., Ramey, A.M., Ely, C.R., Schmutz, J.A., Flint, P.L., Derksen, D.V., Ip, H.S., and Trust, K.A., 2013, Genomic analysis of avian influenza virus from waterfowl in western Alaska, USA: Journal of Wildlife Disease, v. 49, p. 600-610. [Also available at https://doi. org/10.7589/2012-04-108.]

Stech O., Veits, J., Abdelwhab, E.S.M., Wessels, U., Mettenleiter, T.C., and Stech, J., 2015, The neuraminidase stalk deletion serves as major virulence determinant of $\mathrm{H} 5 \mathrm{~N} 1$ influenza viruses in chicken: Scientific Reports, v. 5., Article number 13493, accessed January 25, 2018, at https://www. nature.com/articles/srep13493.

Tsukamoto K., Javier, C.P., Shishido, M., Noguchi, D., Pearce, J., Kang, H.-M., Jeong, O.M., Lee, Y-J., Nakanishi, K., and Ashizawa, T., 2012, SYBR Green-based real-time reverse transcription-PCR for typing and subtyping of all hemagglutinin and neuraminidase genes of avian influenza viruses and comparison to standard serological subtyping tests: Journal of Clinical Microbiology, v. 50, p. 37-45. [Also available at https://doi.org/10.1128/JCM.01195-11.]

Wittwer, C.T., Herrmann, M.G., Moss, A.A., and Rasmussen, R.P., 1997, Continuous fluorescence monitoring of rapid cycle DNA amplification: Biotechniques, v. 22, p. 130-138. 

For additional information, contact: Director, Leetown Science Center U.S. Geological Survey

11649 Leetown Road

Kearneysville, WV 25430

or visit our website at: https://www.lsc.usgs.gov

Publishing support provided by West Trenton Publishing Service Center 


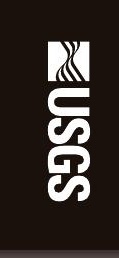

